DOI https://doi.org/10.30525/978-9934-26-113-8-14

\title{
ОРГАНІЗАЦІЯ ПРОВЕДЕННЯ ВЕРИФІКАЦІЇ КІЛЬКІСНИХ МЕТОДІВ ДОСЛІДЖЕННЯ В МЕДИЧИХ ЛАБОРАТОРІЯХ
}

\author{
Сирова Г. О. \\ доктор фармачевтичних наук, \\ завідувач кафедри медичної та біоорганічної хімії \\ Новікова I. B. \\ кандидат медичних наук, \\ асистент кафедри біологічної хімії \\ Харківський національний медичний університет
}

Міщенко Т. О.

біолог експерт багатопрофільної клініко-діагностичної лабораторії КНП ХОР «обласна клінічна лікарня»

Завада О. О.

кандидат фармачевтичних наук, асистент кафедри медичної та біоорганічної хімї Харківський національний медичний університет

\section{Макаров В. О.}

кандидат хімічних наук, доиент кафедри медичної та біоорганічної хімії Харківський національний медичний університет м. Харків, Украӥна

Міжнародні нормативні документи в галузі регулювання якості роботи медичних лабораторій (МЛ) такі як ISO 15189:2012, ISO 17025:2017, CAP і CLIA-88 [1-4], встановлюють вимоги щодо валідації та верифікації методів, які використовують в практичній діяльності працівники лабораторії. Відповідно існуючих норм встановлено, що МЛ повинні провести верифікацію методів, зоною відповідальності більшості медичних лабораторій $є$ верифікація методів, а валідацію аналітичних систем та методів проводять виробники [5-6].

Головним завданням клінічної лабораторії $\epsilon$ надання якісних та достовірних результатів досліджень, тому постає питання у зменшенні 
похибок під час проведення вимірювань настільки, наскільки дозволяють обмеження аналітичних систем. Виходячи 3 того, що в нашій країні використовують тест-системи промислового виробництва, актуальним питанням постає верифікація кількісних методів, які вже валідовані виробниками.

Верифікація передбачає експериментальне підтвердження того, що специфікації заявлені виробником, будуть відтворюватися в будь-якій клініко-діагностичній лабораторії. Метою верифікації $є$ підтвердження спроможності лабораторії отримувати достовірні результати досліджень по валідованому методу. Для проведення верифікації створення певного плану дає змогу виконати ці процедури організованіше та чіткіше, план дій може складатися з таких етапів:

1. Розробити програму верифікації;

2. Визначити аплікаційні, методологічні та аналітичні вимог до тесту. Встановити вимоги до якості тесту у вигляді допустимої загальної помилки визначення або згідно специфікації виробника;

3. Визначити необхідні експерименти, визначити кількість даних, які необхідно зібрати, визначити прийнятні (бажані) концентрації або аналітичні діапазони, в межах яких необхідно зібрати дані;

4. Скласти графік персоналу лабораторії із вказанням часу, відповідно до якого співробітники будуть виконувати верифікаційні експерименти;

5. Підготувати робочі листи, в яких має бути зазначено кількість даних, які слід зібрати в різних експериментах;

6. Вносити данні до електронного протоколу або таблиці Excel щоденно. Виявивши суперечливі результати, виконати повторне тестування зразків за допомогою двох методів;

7. Виконати статистичні розрахунки, використовуючи зібрані в різних експериментах дані;

8. Виконати оцінку прийнятності аналітичної ефективності методу для лабораторії, використовуючи графік прийняття рішення;

9. Задокументувати результати дослідження верифікації методу у вигляді протоколу верифікації. Якщо аналітична ефективність методу буде прийнятною, тоді, для документування стандартного процесу тестування, підготувати стандартну операційну процедуру (СОП) виконання методу;

10. Підготувати навчальні матеріали для тренінгу персоналу: вибрати відповідні контрольні матеріали, контрольні правила і кількість 
контрольних вимірювань для проведення рутинного моніторингу аналітичної ефективності методу.

На всіх етапах проведення досліджень документування умов має вирішальне значення.

Першим кроком в стандартизації процесів в лабораторії $є$ документування всіх процедур, які виконуються в лабораторії, у вигляді СОП. СОП з проведення верифікації методів дослідження повинна описувати поетапне виконання плану верифікації. Також доцільно включати такі дані: пояснення того, що таке верифікація і чому її виконують; формулювання технічних специфікацій; для кожного експерименту вказати порядок проведення, критерії оцінки, періодичність; аналіз верифікації, що проводиться для того, щоб переконатися, що метод дослідження відповідають технічним специфікаціям

СОП повинна бути написана відповідно до протоколу написання процедурної СОП. Для перевірки і затвердження даної СОП потрібно обрати таких співробітників, які знають, що таке валідація/верифікація і чому і як вона проводиться. Провести тренінг з персоналом з поясненням концепції валідації/верифікації так, щоб всі розуміли іï суть, а також необхідність валідації/верифікації методів досліджень і обладнання. Повноваження персоналу встановлюються відповідно до внутрішньої структури лабораторії. Персонал, який задіяний в процесі, повинен пройти навчання. Фахівці, які беруть участь у верифікації, повинні мати досвід самостійної роботи не менше 3 місяців, вивчити методику аналізу.

Згідно робочих характеристик, які слід перевірити, визначають верифікаційні експерименти i дії, які необхідні для проведення цих експериментів. Верифікація проводиться шляхом аналізу зразків, 3 подальшим розрахунком верифікаційних критеріїв. Верифікація вважається успішною при виконанні критеріїв прийнятності.

Одним із перших етапів проведення верифікації $\epsilon$ створення програми верифікації. Вона повинна містити такі дані:

1. Де проводиться верифікація;

2. Назва методу;

3. Причина валідації;

4. Робочі характеристики, які будуть перевірені;

5. Перелік валідаційних параметрів, згідно специфікації виробника;

6. Перелік експерементальних досліджень, що будуть проводитись;

7. Порядок реєстрації результатів досліджень;

8. Термін проведення робіт. 
Наступним етапом проведення верифікації методів дослідження $\epsilon$ розроблення i затвердження протоколу верифікації. Для кожного верифікаційного експерименту доцільно розробляти окремий протокол. Протокол верифікації може складатися з таких пунктів:

1. Об'єкт и мета верифікації;

2. Відомості про валідацію методу;

3. Місце проведення верифікації (лабораторія);

4. Вимоги до персоналу, який проводить верифікацію;

5. Робочі характеристики методу, які слід перевірити;

6. Порядок проведення верифікації;

7. Зразки для верифікації та стандартні зразки;

8. Критерії прийнятності при верифікації;

9. Обладнання, яке використовується при верифікації.

Після проведення верифікації необхідно скласти звіт. Звіт відображає результаті випробувань, проведених згідно до протоколу, який повинен представляти дані у вигляді демонстрації підсумків порівняння результатів досліджень із критеріями прийнятності. Це забезпечує змогу точного і чіткого розуміння прийнятих рішень щодо відповідності методу специфікаціям виробника. Звіт може містити такі дані:

1. Опис методу випробувань;

2. Опис методу аналізу (прийому оцінювання);

3. Опис аналіту/показника, що підлягає аналізу;

4. Витратні матеріали, що використовуються при проведенні ви-пробувань;

5. Валідаційні параметри (робочі характеристики) методу випробувань;

6. Опис обладнання;

7. Проведення випробувань;

8. Експериментальні дані результатів випробувань.

9. Обробка експериментальних даних;

10. Оцінки критеріїв застосування методу;

11. Умови проведення повторної верифікації методу;

12. Висновки щодо придатності методу випробувань до використання.

Аналіз сучасної літератури щодо забезпечення якості та детальне вивчення вимог міжнародних та національних стандартів щодо валідації та верифікації в МЛ, дозволили розробити алгоритм проведення верифікації методів лабораторних досліджень в клінічній лабораторії. Встановлено, що основними етапами верифікації є створення програми, протоколу та звіту щодо проведення досліджень. 


\title{
Література:
}

1. CAP Laboratory Accreditation Checklists. College of American Pathologists (CAP).325 Waukegan Road, Northfield, IL 60093-2750 http://www.cap.org

2. CLSI C28-A3 Defining, Establishing, and Verifying Reference Intervals in the Clinical Laboratory - Third Edition; Approved Guideline, CLSI: Wayne, PA., 2008

3. CLSI EP15-A2 User verification of performance for precision and trueness - Second Edition; Approved Guideline, CLSI: Wayne, PA., 2005

4. Development of national laboratory policies. Best practices document and facilitators' guide. WHO Regional Office for Europe, 2017. - $87 \mathrm{p}$

5. htpp://www.cms/gov/clia/

6. James $\mathrm{O}$. Westgard, $\mathrm{PhD}$. Internal quality control: planning and implementation strategies. http://www.westgard.com/downloads/cat_view/ 52-papers

DOI https://doi.org/10.30525/978-9934-26-113-8-15

\section{ОПРЕДЕЛЕНИЕ И КОРРЕГИРОВАНИЕ ПСИХОЭМОЦИОНАЛЬНОГО НАПРЯЖЕНИЯ ПРИ ИШЕМИЧЕСКОЙ БОЛЕЗНИ СЕРДЦА, ГИПЕРТОНИЧЕСКОЙ БОЛЕЗНИ И СОМАТОФОРМНЫХ РАССТРОЙСТВАХ}

\author{
Сисецкий А. П. \\ кандидат медицинских наук, \\ ассистент кафедры Внутренней медицины № 3 \\ Национальный медицинский университет имени А. А. Богомольиа \\ г. Киев, Украина
}

Сердечно-сосудистые заболевания, в частности ишемическая болезнь сердца (ИБС) и гипертоническая болезнь (ГБ) характеризуются высоким уровнем неконтролированого психоэмоционального напряжения, особенно в сочета-нии с тревожно-депрессивными расстройствами. Этому способствует и не-адекватная психологическая реактивность таких пациентов. Для визуализа-ции психоэмоциональных расстройств при ИБС, ГБ, соматоформных расст-ройствах (СФР) и контроля процесса их коррекции разработаны «Тестовая самоидентификационная система» (ТЕCС) и методика «Самооценки уровня психоэмоционального напряжения» (СУПН). 